\title{
Environmental Managerial Role Study of China Listed Company
}

\author{
Huixuan Chen \\ Northeast normal university \\ NENU \\ Changchun, China \\ chenhx931@nenu.edu.cn
}

\author{
Kangjuan LV \\ Shanghai University \\ SHU \\ Shanghai, China
}

\begin{abstract}
China's economy grows rapidly in last 30 years since opening and reforming policy. However, the environment is destroyed greatly because of companies' pollution. Big corporate play an important role to solve the problem. In this paper, the key literatures about the environmental management strategy, environmental performance and financial performance are summarized. And it generalizes that different environmental management strategies has different impact to environment and financial performance. Based on multiregression analysis of 104 big Listed Companies, this paper demonstrate that there is no correlation between environmental management and environmental performance in China's company.
\end{abstract}

Keywords-Environmental management; environmental performance; financial performance, natural resource base

\section{INTRODUCTION}

The economic growth of our country has drawn the attention of the world. Environmental problem has been restricted our country's sustainable development.

consensus has been reached increasing as basic of social economic activity enterprises mast take both business performance and environmental pollution seriously. Environmental management has been a main working way. Take environment protection as cumbersome of profit at this stage a lot of enterprise's environmental management still at low level.

Since 1960s to 1990s environmental management has run to reaction type model and then to environmental management made. From 1970s relevant between environmental management performance and firm financial performance had been researched in western Europe the us and japan has obtained a large number of achievement. More and more empirical research results confirmed those two are positive correlation. Because of data deficiency study of enterprise environment management acting are less in china.

\section{A. literature summarized}

Relevant between environmental management performance and firm financial performance has researched by Western scholar and reached elegant achievement.According to balance theory of Neo-classicism economic ( Trade-off Theory) the only obligation of company is to improve profit maximizing shareholder value. Enterprise to perform environmental responsibility is too high and unfair to shareholders. On the side of Mmanagerial opportunism hypothesis present by Preston and
O’Bannon(1997). When the corporate short-term financial performance maximum to make up the personal utility, management will reduce the performance of environmental responsibility. According to the theory of supply and demand and cost - benefit analysis framework, the enterprise in order to achieve the profit maximization will provide a specific to meet the request of the environmental performance levels Environment almost belongs to public products lack of property rights, so enterprise itself have no motivation about environmental pollution regulation.

Iraldo (2009) from the angle of environment and competition explore the environmental management system under regulation of EMAS is no significant influence of competitive. Stakeholder theory start with interest group there is positive correlation between environment management performance and business performance. Western environmental management strategy points out that due to stakeholder pressure, supply chain position, resource constrains, organizational barriers, ecological factors, the enterprises will take from reactive to active environment response behavior. Aragon and Sharma (2003) integrated the contingency theory, dynamic capability theory and the natural resource base. Enterprise could improve the environment and competition at the same time but combined with other strategic management and production process development furthermore to invest in pollution prevention technology instead of pollution control for the active environmental strategies.

\section{B. literature review}

Based on the review of theoretical and empirical research the environmental management can affect the operating performance of enterprises.

Although the correlation studies of the environmental management performance and business performance developing in western. There are still lack of studies about the third world countries. Lack of effects study about environmental management with control variables e.g. industry, region, etc and the mediation variables such as enterprise resource, capability and competitive advantage. Traditional financial index and the measure of market such as may have a deviation.

Based on literature analysis this study empirical research on china's listed company. Hypothesis is on the basis of theoretical analysis using empirical method to proving. To discuss the effect of environmental management by theory and practice for large listed companies in china. Samples are included not only manufacturing enterprise but non 
manufacturing enterprise. This is the first time to pay attention to environmental behavior of non manufacturing enterprises.

In this paper financial index has been improved to accurately reflect enterprise's financial performance.

Environmental managerial role positive of china listed company

\section{ENVIRONMENTAL MANAGERIAL ROLE POSITIVE OF CHINA LISTED COMPANY}

\section{A. main variables and source of data}

104 listed companies which disclosed in article of 'China's top 300 enterprises of corporate social responsibility development index' are the sample selected from "Research report on corporate social responsibility of china" published by Research center for corporate social responsibility Chinese academy of social sciences (CASSCSR) in 2011.Take ISO14001as variable of environmental management, for CEM. Enterprises' environmental monitoring record from all levels of government as main variable of corporate environmental performance, for CEP. Public protests can be searched on the internet about sample companies exposure by media included in this study.

Financial performance and non-financial performance were used to measure the performance of enterprises. The improved return on assets (iROA) and return on equity (iROE) from 2009 to 2011 used as variables of enterprise financial performance. What is suitable for the cross-industry comparison. Non-financial performance in this study is enterprise's performance in the capital market. Take the average stock price in 2010 and 2011 (ASP10, ASP11) as variables.

Industry is an important variables for enterprise environment. According to the "name list of key monitoring company in 2011 " divided industry into key monitoring industry and no monitoring industry.

Mining, electric power, gas, production and supply of water, transportation and warehousing are key monitoring industry. Financial, insurance, wholesale and retail real estate are no monitoring industry. Let DI is industry. Let key monitoring company is 0 no monitoring company 1 .

Nature of business is another important influencing factor for enterprise environment. Compare with private enterprise, state-owned enterprise have more supervision pressure from government and the public and more opportunity to get government environmental protection subsidy and preferential policies. State-owned enterprise may not be so strong to pursue short-term economic interests. Let DS is nature of business. Regional economic development degree also can influence enterprise environment mark as DR.

Table 1:MAIN VARIABLES AND SOURCE OF DATA

\begin{tabular}{|l|l|l|l|l|}
\hline \multicolumn{1}{|c|}{ variable } & \multicolumn{1}{c|}{$\begin{array}{c}\text { proxy } \\
\text { variable }\end{array}$} & mark & $\begin{array}{l}\text { standard of } \\
\text { evaluation }\end{array}$ & $\begin{array}{l}\text { source of } \\
\text { data }\end{array}$ \\
\hline $\begin{array}{l}\text { Environment } \\
\text { al } \\
\text { management }\end{array}$ & ISO14001 & CEM & $\begin{array}{l}\text { time of } \\
\text { obtained } \\
\text { certificate }\end{array}$ & $\begin{array}{l}\text { Management } \\
\text { system and } \\
\text { voluntary } \\
\text { product } \\
\text { certification }\end{array}$ \\
\hline
\end{tabular}

\begin{tabular}{|c|c|c|c|c|}
\hline & & & & $\begin{array}{l}\text { certificate } \\
\text { inquiry }\end{array}$ \\
\hline $\begin{array}{l}\text { Environment } \\
\text { al } \\
\text { performance }\end{array}$ & $\begin{array}{l}\text { Record of } \\
\text { environme } \\
\text { nt } \\
\text { supervision }\end{array}$ & CEP & $\begin{array}{l}\text { Complain, } \\
\text { administrativ } \\
\text { e penalty, } \\
\text { penalty, } \\
\text { suspend } \\
\text { business to } \\
\text { bring up to } \\
\text { standard }\end{array}$ & $\begin{array}{l}\text { State } \\
\text { certification } \\
\text { and } \\
\text { accreditation } \\
\text { regulatory } \\
\text { commission } \\
\text { Public } \\
\text { environment } \\
\text { al research } \\
\text { center } \\
\text { terprise } \\
\text { environment } \\
\text { al monitoring } \\
\text { information } \\
\text { data retrieval }\end{array}$ \\
\hline $\begin{array}{l}\text { Financial } \\
\text { performance }\end{array}$ & $\begin{array}{l}\text { Improved } \\
\text { return on } \\
\text { assets and } \\
\text { return on } \\
\text { equity from } \\
2009 \text { to } \\
2011\end{array}$ & $\begin{array}{l}\text { iROE0 } \\
9 \\
\text { iROA0 } \\
9 \\
\text { iROE1 } \\
0 \\
\text { iROA1 } \\
0 \\
\text { iROE1 } \\
1 \\
\text { iROA1 } \\
1\end{array}$ & 1 & $\begin{array}{l}\text { CSMAR } \\
\text { Solution } \\
\text { CSMAR } \\
\text { china listed } \\
\text { companies } \\
\text { data base } \\
\text { CSMAR } \\
\text { china stock } \\
\text { market data }\end{array}$ \\
\hline $\begin{array}{l}\text { Non-financial } \\
\text { performance }\end{array}$ & $\begin{array}{l}\text { average } \\
\text { stock price } \\
\text { in } 2010 \text { and } \\
2011\end{array}$ & $\begin{array}{l}\text { ASP10 } \\
\text { ASP11 }\end{array}$ & & base \\
\hline \multirow{3}{*}{$\begin{array}{l}\text { Control } \\
\text { variable }\end{array}$} & industry & DI & $\begin{array}{l}\text { Key } \\
\text { monitoring } \\
\text { evaluate } 1 \\
\text { Non-key } \\
\text { monitoring } \\
\text { evaluate } 0\end{array}$ & \multirow{3}{*}{$\begin{array}{l}\text { CSMAR } \\
\text { Solution } \\
\text { CSMAR } \\
\text { china stock } \\
\text { market data } \\
\text { base }\end{array}$} \\
\hline & $\begin{array}{l}\text { Enterprise } \\
\text { property }\end{array}$ & DS & $\begin{array}{l}\text { State-owned } \\
\text { business } \\
\text { evaluate } 1 \\
\text { Private } \\
\text { enterprise } \\
\text { evaluate } 0\end{array}$ & \\
\hline & region & DR & $\begin{array}{l}\text { Undeveloped } \\
\text { area evaluate } \\
1 \\
\text { Developed } \\
\text { area evaluate } \\
0\end{array}$ & \\
\hline
\end{tabular}

B. positive analysis and results.

Because of too many variables, this study adopts application stepwise regression program of Eviews6.0 to select variables. According to the selected variables assumptions and results of stepwise regression, there are four test model been designed.

$\mathrm{CEP}=\mathrm{c}(0)+\mathrm{c}(1) * \mathrm{CEM}+\mathrm{c}(2) * \mathrm{iROA} 10+\mathrm{c}(3) * \mathrm{iROE} 09$ $+\mathrm{c}(4) * \mathrm{iROE} 11+\mathrm{c}(5) * \mathrm{ASP} 10+\mathrm{c}(6) * \mathrm{ASP} 11+\mathrm{c}(7) * \mathrm{DI}+$ $\mathrm{c}(8) * \mathrm{DS}+\mathrm{c}(9) * \mathrm{DR}$

$\mathrm{CEM}=\mathrm{c}(10)+\mathrm{c}(11) * \mathrm{iROA} 10+\mathrm{c}(12) *$ iROE09 + $\mathrm{c}(13) * \mathrm{ASP} 10+\mathrm{c}(14) * \mathrm{DI}+\mathrm{c}(15) * \mathrm{DS} \quad$ (2)

$\mathrm{iROA} 10=\mathrm{c}(21)+\mathrm{c}(22) * \mathrm{CEM}+\mathrm{c}(23) * \mathrm{CEP}+\mathrm{c}(24) * \mathrm{DI}$ $+\mathrm{c}(25) * \mathrm{DS}+\mathrm{c}(26) * \mathrm{DR}$ 
ASP11 $=\mathrm{c}(27)+\mathrm{c}(28) * \mathrm{CEM}+\mathrm{c}(29) * \mathrm{CEP}+\mathrm{c}(30) * \mathrm{DI}+$ $\mathrm{c}(31) * \mathrm{DS}+\mathrm{c}(32) * \mathrm{DR}$

In this study all extreme value data are deleted. Using Correlated Random Effect-Hausman Test to test influence between variables. The result of Correlated Random EffectHausman Test and the OLS are not different. So this model is no significant endogeneity problem. Least-squares regression used for each model. Based on white test and coefficient index test those which inconformity the classical linear regression equation will be coordinate with WLS.

Base on every multiple regression analysis we can conclude as following. 1) Environmental management for large listed company is not significant influence with environmental performance. 2) In short term, large listed company's environmental performance is negative correlation relationship with firm's performance. 3) In short term, large listed company's environmental responsibility is negative or no correlation relationship with business performance. 4) large listed company's performance have no significant influence with environmental management.

The regression results of model 1 as table 2, environmental management have no significant influence with business performance. Environmental management of most enterprises in our country is still at the primary stage. Main point of environment management is let the pollutant emissions achieved the national or local regulations. Most enterprises still in "governance after the pollution" the traditional terminal governance model.

Table 2 is the regression results about model 2. iROA10 and ASP10 are significant negative correlation with CEM. Enterprise's environmental management have no significant correlation with iROE09. But the Adjusted R-squared in this model is too small only 0.048442. Goodness of fit is very unhealthy in model 2, so t-value couldn't be used. Our country's large listed company's performance have no influence or negative correlation with environmental management.e template is used to format your paper and style the text. Aorell marginhat anticipate your paper as one part of the entire proceedings, and not as an ind

Table 2 MULTIPLE REgRESSION RESULt 1

\begin{tabular}{|c|c|c|}
\hline \multirow{2}{*}{ Multiple regression result1 } & model (2) & model(1) \\
\hline & \multicolumn{2}{|c|}{ Explained variable } \\
\hline Explaining variable & CEM & CEP \\
\hline CEM & & $\begin{array}{l}0.00620 \\
(0.05856)\end{array}$ \\
\hline iROE09 & $\begin{array}{l}-0.27332 \\
(0.25256)\end{array}$ & $\begin{array}{l}0.11003 \\
(0.22895)\end{array}$ \\
\hline iROA10 & $\begin{array}{c}-0.01690 * * * \\
(0.00365)\end{array}$ & $\begin{array}{r}-0.00941 * * \\
(0.00381)\end{array}$ \\
\hline iROE11 & & $\begin{array}{l}1.76402 \\
(1.28164)\end{array}$ \\
\hline ASP10 & & $\begin{array}{r}-0.01034 \\
(0.01823)\end{array}$ \\
\hline ASP11 & $-0.035514 * * *$ & 0.00856 \\
\hline
\end{tabular}

\begin{tabular}{|l|l|l|} 
& $(0.01245)$ & $(0.01959)$ \\
\hline DS & $\begin{array}{c}-0.59980 \\
(0.48248)\end{array}$ & $\begin{array}{c}0.36854 \\
(0.22731)\end{array}$ \\
\hline DR & & $\begin{array}{c}-0.50462 \\
(0.40087)\end{array}$ \\
\hline DI & 0.66425 & 0.39884 \\
$(0.47440)$ & $(0.34851)$ \\
\hline C & $1.89122^{* * *}$ & $2.94323^{* * *}$ \\
& $(0.45539)$ & $(0.45025)$ \\
\hline N & 104 & 104 \\
\hline R-squared & 0.10387 & 0.99871 \\
\hline OLS/WLS & OLS & WLS \\
\hline Hypotheses & H4a & H1+H4b \\
\hline
\end{tabular}

Table 3 Multiple RegresSION RESULt 2

\begin{tabular}{|c|c|c|}
\hline \multirow{2}{*}{ Multiple regression result 2} & model (4) & model (5) \\
\hline & \multicolumn{2}{|c|}{ Explained variable } \\
\hline Explaining variable & iROA10 & ASP11 \\
\hline CEM & $\begin{array}{l}-0.00517^{* * *} \\
(0.00000)\end{array}$ & $\begin{array}{l}2.06072^{* * *} \\
(0.23030)\end{array}$ \\
\hline CEP & $\begin{array}{l}-0.06805^{* * *} \\
(0.02144)\end{array}$ & $\begin{array}{l}4.18707^{* * *} \\
(0.25173)\end{array}$ \\
\hline DS & $\begin{array}{c}-0.07570^{* * *} \\
(0.00000)\end{array}$ & $\begin{array}{r}2.80217^{* * *} \\
(0.69090)\end{array}$ \\
\hline DR & $\begin{array}{r}0.07061^{* * *} \\
(0.00000)\end{array}$ & $\begin{array}{r}-4.88316^{* *} \\
(2.31953)\end{array}$ \\
\hline DI & $\begin{array}{l}0.01884 \\
(0.02144)\end{array}$ & $\begin{array}{l}-4.99324 \\
(4.14193)\end{array}$ \\
\hline $\mathrm{C}$ & $\begin{array}{l}0.16418^{* * *} \\
(0.04289)\end{array}$ & $\begin{array}{c}-9.23963 * \\
(4.86491)\end{array}$ \\
\hline $\mathrm{N}$ & 104 & 104 \\
\hline R-squared & 1 & 0.99999 \\
\hline OLS/WLS & WLS & WLS \\
\hline Hypotheses & $\begin{array}{l}\mathrm{H} 2 \mathrm{a}+\mathrm{H} 2 \mathrm{~b} \\
+\mathrm{H} 3 \mathrm{a}+\mathrm{H} 3 \mathrm{~b}\end{array}$ & $\begin{array}{l}\mathrm{H} 2 \mathrm{a}+\mathrm{H} 2 \mathrm{~b} \\
+\mathrm{H} 3 \mathrm{a}+\mathrm{H} 3 \mathrm{~b}\end{array}$ \\
\hline
\end{tabular}

***, **, * are $1 \%, 5 \%$ and $10 \%$ significance level. Values in brackets are standard errors.

In short term environment performance is negative correlation with finance performance by model 3. As table six in short term CEP is negative correlation with iROA10. Model 4 show as table 3 CEP is negative correlation with ASP11. Environmental performance have a hysteretic impact on operating performance. The positive impact of 2010 and 2011 annual environmental performance on 2010 and 2011 for business performance. Buying expensive unproductive equipment to improve environment performance increase the financial burden. Model four seems illogical. Stock of Zijin 
consortium rocket up just after environmental pollution event It was a example illustration for this result.

Now our country's large listed company's environmental management is at first degree. Model three and model four could checking environmental management strategic theory, dynamic capability theory and nature base. Stock could show investor's expect of enterprise state of operation, but there are many other factor affected. Model four is more complex.

\section{CONCLUSION AND SUGGESTION}

In this paper, environmental managerial role be test. Through the multiple regression analysis of 104 large listed companies in China. Research findings large listed company's environmental responsibility have no significant influence environmental performance. Environmental performance have negative or no correlation relationship with firm's performance. Environmental management have negative or no correlation relationship with firm's performance. Environmental responsibility have negative or no correlation relationship with Environmental performance. Industry, enterprise nature and geographical factors are also important to environmental responsibility. State-owned enterprises or registered enterprise in undeveloped area have significant negative correlation relationship.

Improve the environment from the side of enterprises government and social. Enterprises should confirm a clear environment target to improve problem solved ability, built c common wish and green courter. Government should pay more attention on environment guard and reward, complete the law. Especially in undeveloped area.

Popularize environmental protection knowledge is responsibility of government. To the public actively used the consumer's preference and join the game of company and government will help the environmental managerial develop towards positive and initiative.

There must be a little bit deviation take stock as Nonfinancial performance index in this study. Our country's stock market still at initial stage. Stock couldn't show the company's expect future. This study just discuss about the relationship between Environmental performance and firm's performance in short-term. So middle and long term need more research.

\section{REFERENCES}

[1] Friedman, M. (1962) Capitalism and Freedom. University of Chicago Press, Chicago.
[2] Salzmann O, Ionescu-somers A, Steger U. The Business Case for Corporate Sustainability: Literature Review and Research Options [J]. European Management Journal. 2005, 23(1): 27-36

[3] Ansel. M. sharp, Charles A. Regis, Paul W. grimes. Economics of social issues (18e)[M]. Beijing: china renmin university press ,2009: 72-90.

[4] Lv Jun, JiaoShuYan. Environmental disclosure an empirical study of relationship between environmental performance and financial performance $[\mathrm{J}]$. Journal of Shanxi Finance and Economics University. 2011, 33(1):109—116.

[5] López-Gamero MD, Molina-Azorín JF, Claver-Cortés E. The whole relationship between environmental variables and firm performance: Competitive advantage and firm resources as mediator variables [J]. Journal of Environmental Management. 2009, 90(10): 3110-3121

[6] Pava, M.L. and Krausz, J. (1996) the association between corporate social-responsibility and financial performance: The paradox of social cost. Journal of Business Ethics 15, 321-357

[7] Preston, L.E. and O'Bannon, D.P. (1997) the corporate socialfinancial performance relationship: A typology and analysis. Business and Society 36(4), 419-429.

[8] Waddock, S.A. and Graves, S.B. (1997b) the corporate social performance-financial performance link. Strategic Management Journal 18(4), 303-319.

[9] Satish Joshi, 2001“Estimating the hidden costs of environmental regulation” The Accounting Review, Vol. 76, pp.11-13.

[10] Henri, J.-F., Journeault, M., 2008. Environmental performance indicators: an empirical study of Canadian manufacturing firms. Journal of Environmental Management 87, 165-176.

[11] Schaltegger, S., Figge, F., 2000. Environmental shareholder value: economic success with corporate environmental management. EcoManagement and Auditing P 29-42.

[12] Wagner, M., Schaltegger, S., 2004. The effect of corporate environmental strategy choice and environmental performance on competitiveness and economic performance: an empirical study of EU manufacturing. European Management Journal 22, 557-572.

[13] $\mathrm{Hu}$ Meiqin, Li Yuanxu. western enterprise management research review and enlightenment[J].management review. 2007, 19(12)

[14] Christmann, P.and G. Taylor. Globalization and the environment: Strategies for international voluntary environmental initiatives. Academy of Management Executive, 2002, 16 (3):121- 135

[15] Hart,S.L. A natural-resource-based view of the firm. Academy of Management Review, 1995, 20(4):986- 1014

[16] Hart,S.L. Beyond greening: Strategies for a sustainable world. Harvard Business Review, 1997, 75 (1):66- 76

[17] Klassen, R.D., McLaughlin, C., 1996. The impact of environmental management on firm performance. Management Science 42, 11991214.

[18] S.X. Zeng et al. Towards implementation of ISO 14001 environmental management systems in selected industries in China. Journal of Cleaner Production 2005 (13): 645-656 